\title{
У Kouluterveydenhuollon suunnitelmallisuus ja yhtenäinen taso kouluterveydenhuollon toimintaohjelmien valossa
}

Kouluterveydenhuollon tulee olla suunnitelmallista, laadukasta ja tasoltaan yhtenäistä. Vuonna 2009 annettu asetus velvoittaa kuntia tekemään yhtenäisen toimintaohjelman lasten ja nuorten ehkäiseville terveyspalveluille. Tutkimuksessa arvioidaan kouluterveydenhuollon suunnitelmallisuutta ja yhtenäistä tasoa toimintaohjelmien avulla. Vertailukelpoista arviointia varten kehitimme toimintaohjelmamittarin. Mittari ja arvioinnin tulos kuvataan artikkelissa.Aluehallintovirastot keräsivät toimintaohjelmat alueensa terveyskeskuksista $201 \mathrm{I}-2012(\mathrm{~N}=136,87 \%)$. Arviointiin kehitettiin mittari, joka koostuu 38:sta säädöksiin perustuvasta indikaattorista. Nämä ryhmiteltiin seitsemään ulottuvuuteen (sitoutuminen, johtaminen, yhteistyö, voimavarat, laajat terveystarkastukset, muut terveystarkastukset ja terveysneuvonta, erityinen tuki). Mittarin maksimipisteet olivat 76.

Toimintaohjelmien kouluterveydenhuoltoa koskevat osat arvioitiin mittarin avulla. Toimintaohjelmien kokonaispisteet vaihtelivat välillä 0-70 (0-92\% maksimista). Keskiarvo oli 39.6 (52\%). Seitsemästä ulottuvuudesta matalimmat pisteet sai voimavarat (2,7/8 pistettä) ja korkeimmat muut terveystarkastukset ja terveysneuvonta (7,3/I2 pistettä). Suurten terveyskeskusten toimintaohjelmat saivat korkeammat pisteet $(46,5)$ kuin pienempien $(29,5)$. Ensimmäiset asetuksen mukaiset toimintaohjelmat olivat vaihtelevia ja niiden suunnittelussa todettiin puutteita. Kehitetyn mittarin avulla kouluterveydenhuoltoa voidaan arvioida vertailukelpoisesti yli koko maan. Nyt raportoidut tulokset toimivat perustasona kouluterveydenhuollon seurannassa. Mittaria voidaan soveltaa myös muille alueille ja hyödyntää kouluterveydenhuollon kehittämisessä sosiaali- ja terveydenhuollon uudistuksen yhteydessä.

\section{ASIASANAT: Kouluterveydenhuolto, toimintaohjelma, arviointi, mittari \\ MARJUT FRANTSI-LANKIA, HANNE KIVIMÄKI, KIRSI WISS, VESA SAARISTO, TIMO STAHL, ARJA RIMPELÄ}

\section{JOHDANTO}

Kouluterveydenhuolto on koululaisten ja perheiden helposti saatavilla olevaa suunnitelmallista toimintaa, joka järjestetään koulussa osana opiskeluhuoltoa (1-4). Se on olennainen osa ehkäiseviä terveyspalveluja, joiden tavoitteena on tukea ja edistää oppilaiden tervettä kasvua, kehitystä ja hyvinvointia. Kouluterveydenhuolto on järjestettävä tasoltaan yhtenäisenä ja väestön tarpeet huomioiden. Laadukkaat monialaiset palvelut edellyttävät yhteisiä toimintalinjoja, suunnittelua sekä seurantaa ja säännöllistä arviointia (2-7). Kouluterveydenhuoltoon kuuluvat määräaikaisten terveystarkastusten ja terveysneuvonnan lisäksi myös kouluympäristön terveellisyyden ja turvallisuuden sekä kouluyhteisön hyvinvoinnin edistäminen (1-6,8). Kouluterveydenhuollon sisältö esitetään taulukossa 1 . 
Taulukko 1. Kouluterveydenhuoltoon sisältyvät tehtävät.

\begin{tabular}{|c|c|}
\hline $\begin{array}{l}\text { - Oppilaan kasvun, terveyden ja hyvinvoinnin } \\
\text { seuraaminen ja edistäminen vuosiluokittain }\end{array}$ & $\begin{array}{l}\text { - Terveystarkastus jokaisella vuosiluokalla ja } 1 ., 5 \text {. ja } 8 . \\
\text { luokalla laaja terveystarkastus } \\
\text { - Terveysneuvonta sekä hyvinvoinnin ja terveyden } \\
\text { edistäminen } \\
\text { - Henkilökohtaisen terveyssuunnitelman tekeminen } \\
\text { - Ennaltaehkäisevät toimenpiteet kuten rokotus ja } \\
\text { fluorikorvaus } \\
\text { - Terveystieto/terveyskasvatus } \\
\text { - Avoin vastaanotto }\end{array}$ \\
\hline - Oppilaan vanhempien/huoltajien tukeminen & $\begin{array}{l}\text { - Laajaan terveystarkastukseen kutsutaan mukaan oppilaan } \\
\text { vanhemmat } \\
\text { - Oppilaan vanhempien tukeminen (kasvatustehtävässä) }\end{array}$ \\
\hline - Oppilaan suun terveydenhuolto & $\begin{array}{l}\text { - Määräaikaiset suun terveydenhuollon tarkastukset 1., 5. ja } \\
\text { 8. vuosiluokilla } \\
\text { - Suun terveydenhuolto ja suun terveyden edistäminen }\end{array}$ \\
\hline $\begin{array}{l}\text { - Erityisen tuen tai tutkimusten tarpeen } \\
\text { varhainen tunnistaminen ja tukeminen }\end{array}$ & $\begin{array}{l}\text { - Erityisen tuen tarpeen varhainen tunnistaminen (esim. } \\
\text { huolen vyöhykkeistö) } \\
\text { - Tarvittavien tutkimusten ja tuen järjestäminen (interventio) } \\
\text { - Pitkäaikaisesti sairaan lapsen omahoidon tukeminen } \\
\text { - Yhteistyö oppilashuollon kanssa }\end{array}$ \\
\hline $\begin{array}{l}\text { - Terveydentilan toteamista varten tarpeelliset } \\
\text { erikoistutkimukset }\end{array}$ & $\begin{array}{l}\text { - Lähetteet erikoistutkimuksiin tarvittaessa (mm. korva- ja } \\
\text { silmälääkäri, lasten ja nuorten psykiatri) }\end{array}$ \\
\hline $\begin{array}{l}\text { - Kouluympäristön terveellisyyden ja } \\
\text { turvallisuuden sekä kouluyhteisön } \\
\text { hyvinvoinnin edistäminen sekä seuranta }\end{array}$ & $\begin{array}{l}\text { - Kouluympäristön terveellisyyden ja turvallisuuden sekä } \\
\text { kouluyhteisön hyvinvoinnin tarkastus kolmen vuoden } \\
\text { välein } \\
\text { - Tarkastuksissa todettujen puutteiden korjaamisen seuranta } \\
\text { vuosittain }\end{array}$ \\
\hline
\end{tabular}

Lähteet: www.stm.fi, www.thl.fi

Kouluterveydenhuollosta tuli 1972 kansanterveyslain myötä osa terveyskeskustoimintaa, jonka suunnittelua ohjeistettiin Lääkintöhallituksen ohjekirjeillä (9-11). Valtionosuusuudistuksessa 1993 kansanterveystyön lakisääteinen suunnittelu- ja seurantavelvoite poistettiin, jolloin kuntien vapaus palvelujen järjestämisessä lisääntyi $(12,13)$. Kansanterveyslakiin jäi vain yleinen velvoite järjestää kouluterveydenhuollon palvelut. Samaan aikaan taloudellinen lama johti kunnissa kouluterveydenhuollon määräaikaisten terveystarkastusten ja henkilöstövoimavarojen supistuksiin (13-15).

Huoli lasten ja nuorten hyvinvoinnista kasvoi 1990-luvun lopussa, mikä lisäsi kiinnostusta kehittää kouluterveydenhuoltoa ja sen informaatio-ohjausta $(12,16)$. Ohjauksen tavoitteena oli varmistaa palvelujen laatu, yhtenäinen taso ja riittävät toimintaedellytykset koko maassa. Suositusten ohjausvaikutus jäi kuitenkin vähäiseksi eivätkä palvelut ja henkilöstövoimavarat toteu- tuneet tavoitteiden mukaisesti (12,17-20). Myös kouluterveydenhuollon suunnitelmallisuudessa ja johtamisessa todettiin puutteita (21).

Lasten ja nuorten hyvinvointipoliittisesta suunnittelusta tuli vahvemmin kunnan lakisääteinen tehtävä 2000-luvulla $(22,23)$. Neuvolatoimintaa sekä koulu- ja opiskeluterveydenhuoltoa koskevan asetuksen ja terveydenhuoltolain tavoitteina on ollut vahvistaa lasten ja nuorten terveyden edistämistä sekä aikaistaa ja tehostaa varhaista tukea ja syrjäytymisen ehkäisyä (4-6, 24). Asetus on myös velvoittanut kuntia vuodesta 2009 lähtien laatimaan yhtenäisen toimintaohjelman lasten ja nuorten ehkäiseville terveyspalveluille (3-6). Toimintaohjelman tarkoituksena on ollut varmistaa terveysneuvonnan ja -tarkastusten suunnitelmallisuus ja yhtenäinen taso.

Toimintaohjelma, joka valmistellaan yhteistyössä terveystoimen sekä sosiaali- ja sivistystoimen kanssa, on työväline palveluja suunniteltaessa, johdettaessa ja kehitettäessä (25). Toi- 
mintaohjelma tekee toiminnasta läpinäkyvää ja ohjaa yksittäisen työntekijän lisäksi monialaista yhteistyötä yhdenmukaistaen toimintatapoja. Asetuksen voimaantulon jälkeen joka toinen terveyskeskus ilmoitti hyväksyneensä toimintaohjelman (26). Pari vuotta myöhemmin (2012) neljä viidestä terveyskeskuksesta ilmoitti hyväksyneensä sen $(27,28)$. Toimintaohjelmat ovat vaihdelleet laajuudeltaan ja sisällöiltään (28), mutta systemaattisesti niitä ei ole aiemmin arvioitu. Tehtävään soveltuvaa arviointivälinettä ei ollut, minkä vuoksi tässä tutkimuksessa kehitettiin uusi mittari toimintaohjelmien arvioimiseksi.

Mittarin kansainvälisenä perustana olivat WHO:n Health Promotion Hospitals -itsearviointimenetelmä sekä Focus Resources on Effective School Health eli FRESH-viitekehys $(29,30)$. Samanlaista työtä on tehty myös osana terveyden edistämisen, laadunhallinnan ja kouluterveydenhuollon kehittämistä (31-36). Suomalainen terveyden edistämisen vertailutietojärjestelmä TEAviisari, joka kuvaa kuntien terveydenedistämisaktiivisuutta vertailukelpoisella tavalla, toimi kansallisena mallina toimintaohjelmamittarin kehittämisessä (37-39). Kouluterveydenhuoltoa säätelevä asetus, terveydenhuoltolaki sekä kouluterveydenhuollon laatusuositukset loivat hyvän perustan toimintaohjelmamittarin indikaattoreiden valinnalle $(2,5-6,24)$.

\section{TUTKIMUKSEN TAVOITTEET}

Tutkimuksen tavoitteena oli arvioida kouluterveydenhuollon suunnitelmallisuutta ja yhtenäistä tasoa lakisääteisten toimintaohjelmien avulla. Arviointia varten kehitettiin uusi toimintaohjelmamittari, joka mahdollisti toimintaohjelmien vertailukelpoisen arvioinnin. Toimintaohjelmamittarin kehittäminen sekä toimintaohjelmien arvioinnin tulos esitetään tässä artikkelissa.

\section{AINEISTO JA MENETELMÄT}

Kaikki kuusi aluehallintovirastoa, Etelä-Suomen, Lounais-Suomen, Länsi ja Sisä-Suomen, Itä-Suomen, Pohjois-Suomen sekä Lapin aluehallintovirastot (AVI) pyysivät asetuksen mukaiset neuvolatoiminnan, koulu- ja opiskeluterveydenhuollon sekä lasten ja nuorten ehkäisevän suun terveydenhuollon yhtenäiset toimintaohjelmat alueensa terveyskeskuksista osana vuosien 20112012 viranomaisvalvontaa (40).
Suurin osa $(63 \%)$ terveyskeskuksista toimitti pyydetyn yhtenäisen toimintaohjelman. Loput terveyskeskuksista toimitti muita lasten ja nuorten ehkäiseviä terveyspalveluja koskevia tai niihin liittyviä asiakirjoja. Näistä osa oli toimintaohjelmaa laajempia ja yleisempiä (esimerkiksi lasten ja nuorten hyvinvointisuunnitelma, terveydenedistämisen suunnitelma, strategia, laatukäsikirja) ja osa sitä suppeampia. Noin $5 \%$ asiakirjoista koostui vain terveystarkastustaulukoista. Muita asiakirjoja olivat muun muassa toimenpideohjelma, yhteistyötoimintaohje ja kirjallinen vapaamuotoinen vastaus AVI:n selvityspyyntöön.

Aineisto muodostettiin 136 terveyskeskuksen vuoden 2012 loppuun mennessä AVI:lle toimittamien edellä kuvattujen suomenkielisten asiakirjojen (jatkossa toimintaohjelma) kouluterveydenhuoltoa koskevista osista. Se kattoi $86 \%$ terveyskeskuksista ja $87 \%$ väestöstä. Toimintaohjelmien rakenne ja laajuus vaihtelivat (3-200 sivua) ja niiden voimassaoloaika oli yhdestä neljään vuoteen. Noin puolessa toimintaohjelmia ei ollut lainkaan tietoa ohjelman hyväksymisajankohdasta ja/tai voimassaoloajasta. Pohjois-Suomen AVI:n toimialue oli ainoa, josta asiakirjat saatiin kattavasti alueen kaikista terveyskeskuksista.

\section{TOIMINTAOHJELMAMITTARI}

Kouluterveydenhuoltoa kuvaavat indikaattorit (taulukko 2) valittiin toimintaa säätelevän asetuksen $(5,6)$ ja terveydenhuoltolain (24) sekä kirjallisuuden (31) perusteella. Indikaattoreiden sisältö määritettiin ja kirjattiin ylös mahdollisimman tarkasti. Valitut 38 indikaattoria ryhmiteltiin seitsemään kouluterveydenhuoltoa kuvaavaan ulottuvuuteen TEA-viitekehyksen mukaisesti (37-39). Ulottuvuuksiksi muodostuivat 1) sitoutuminen, 2) johtaminen, 3) yhteistyö ja 4) voimavarat sekä 5) laajat terveystarkastukset, 6) muut terveystarkastukset ja terveysneuvonta ja 7) erityinen tuki.

Ulottuvuudet ryhmiteltiin edelleen kahdeksi arviointikokonaisuudeksi, jotka ovat 1) suunnittelu ja johtaminen (neljä ulottuvuutta) sekä 2) kouluterveydenhuollon sisältö (kolme ulottuvuutta). Molemmat arviointikokonaisuudet sisältävät 19 indikaattoria. Ulottuvuuksittain indikaattoreiden määrä vaihtelee neljästä seitsemään. Toimintaohjelmamittarin kokonaisuus esitetään taulukossa 2 . 
Taulukko 2. Toimintaohjelmamittari ja niiden terveyskeskusten osuus, jotka saivat maksimipisteet toimintaohjelmamittarin eri indikaattoreissa.

\begin{tabular}{|c|c|c|}
\hline Ulottuvuus & Indikaattori & $\begin{array}{c}\text { Maksimipisteet saaneiden } \\
\text { terveyskeskusten osuus }\end{array}$ \\
\hline \multicolumn{3}{|l|}{ Suunnittelu ja johtaminen } \\
\hline \multirow[t]{5}{*}{ Sitoutuminen } & Toimintaohjelma tehty & $80,9 \%$ \\
\hline & Valmisteltu yhteistyössä & $24,3 \%$ \\
\hline & Hyväksytty luottamuselimissä & $45,6 \%$ \\
\hline & Seuranta, arviointi, raportointi kuvattu & $30,1 \%$ \\
\hline & Vastuuhenkilö nimetty & $45,6 \%$ \\
\hline \multirow[t]{6}{*}{ Johtaminen } & Toimintaympäristöä kuvattu & $34,6 \%$ \\
\hline & Tavoitteet kuvattu & $55,1 \%$ \\
\hline & Seurantamittarit kuvattu & $21,3 \%$ \\
\hline & Päivittäminen kuvattu & $22,8 \%$ \\
\hline & Kehittäminen kuvattu & $36,8 \%$ \\
\hline & Toimintaohjelman ohjaavuus/konkreettisuus & $43,4 \%$ \\
\hline \multirow[t]{4}{*}{ Yhteistyö } & Oppilashuoltoyhteistyö & $72,8 \%$ \\
\hline & $\begin{array}{l}\text { Kouluympäristön tarkastaminen } 3 \text { vuoden } \\
\text { välein }\end{array}$ & $52,2 \%$ \\
\hline & Tarkastuksessa todettujen puutteiden seuranta & $20,6 \%$ \\
\hline & Hoitoketjuja/verkostoja kuvattu & $39,0 \%$ \\
\hline \multirow[t]{4}{*}{ Voimavarat } & Terveydenhoitaja (oppilas/terveydenhoitaja) & $47,8 \%$ \\
\hline & $\begin{array}{l}\text { Terveydenhoitajavoimavarojen riittävyys } \\
\text { arvioitu }\end{array}$ & $30,1 \%$ \\
\hline & Lääkäri (oppilas/lääkäri) & $20,6 \%$ \\
\hline & Lääkärivoimavarojen riittävyys arvioitu & $11,8 \%$ \\
\hline \multicolumn{3}{|l|}{ Kouluterveydenhuollon sisältö } \\
\hline \multirow[t]{7}{*}{ Laaja terveystarkastus } & Tarkastusten lukumäärä (3 kpl) & $83,8 \%$ \\
\hline & Laajan tarkastuksen kriteerit kirjattu & $35,3 \%$ \\
\hline & Sisältö kuvattu & $24,3 \%$ \\
\hline & Ajankäyttö kirjattu & $29,4 \%$ \\
\hline & Laajojen terveystarkastusten yhteenveto tehdään & $29,4 \%$ \\
\hline & Vanhempien osallistuminen kuvattu & $57,4 \%$ \\
\hline & Opettajan arvio oppilaasta tehdään & $57,4 \%$ \\
\hline \multirow{6}{*}{$\begin{array}{l}\text { Muut terveystarkastukset ja } \\
\text { terveysneuvonta }\end{array}$} & Tarkastusten lukumäärä (6 kpl) & $85,3 \%$ \\
\hline & Sisältö kuvattu & $44,1 \%$ \\
\hline & Ajankäyttö kirjattu & $24,3 \%$ \\
\hline & $\begin{array}{l}\text { Suun terveydenhuollon tarkastusten lukumäärä } \\
(3 \mathrm{kpl})\end{array}$ & $80,1 \%$ \\
\hline & Terveysneuvonta kuvattu & $66,2 \%$ \\
\hline & Terveysneuvontamateriaali kuvattu & $26,5 \%$ \\
\hline \multirow[t]{6}{*}{ Erityinen tuki } & Tarpeen tunnistaminen kuvattu & $48,5 \%$ \\
\hline & Tuen järjestäminen kuvattu & $52,9 \%$ \\
\hline & Kyselylomakkeet ennen tarkastuksia & $64,7 \%$ \\
\hline & Poisjääneiden tuen tarpeen arviointi kuvattu & $41,9 \%$ \\
\hline & Erikoistutkimukset kuvattu & $24,3 \%$ \\
\hline & Hyvinvointisuunnitelma tehdään & $47,8 \%$ \\
\hline
\end{tabular}




\section{PISTEYTTÄMINEN}

Päätutkija pisteytti toimintaohjelmat toimintaohjelmamittarin indikaattoreiden avulla. Toimintaohjelma sai kaksi pistettä kaikista niistä indikaattoreista, jotka oli kirjattu ohjelmaan määritellyn sisällön mukaisena. Jos indikaattoria ei mainittu toimintaohjelmassa lainkaan tai se oli kirjattu vastoin sisältöä, sai toimintaohjelma tästä indikaattorista nolla pistettä. Yhden pisteen toimintaohjelma sai niistä indikaattoreista, jotka oli kirjattu toimintaohjelmaan tulkinnanvaraisesti tai vain osittain indikaattorin sisällön mukaisina.

Ennen pisteyttämistä toimintaohjelma luettiin kokonaisuutena läpi. Toisella lukukerralla toimintaohjelman indikaattoreita sisältävät kohdat identifioitiin ja arvioitiin miten kirjaukset vastasivat kunkin indikaattorin määriteltyä sisältöä. Toimintaohjelman kokonaispisteet muodostuivat kaikkien 38 indikaattorin yhteenlasketuista pisteistä. Teoreettinen maksimipistemäärä oli 76 pistettä. Myös ulottuvuuksien ja arviointikokonaisuuksien pisteet kirjattiin. Ulottuvuuksien pistemäärä ja painoarvo vaihteli niiden sisältämien indikaattoreiden lukumäärän mukaan (814 pistettä). Arviointikokonaisuudet olivat painoarvoltaan samat (taulukko 2).

Pisteytyksen reliabiliteettia arvioitiin siten, että toinen tutkija pisteytti $13(10 \%)$ satunnaisesti eri AVIen alueelta valittua toimintaohjelmaa. Ensimmäisellä arviointikerralla toisen tutkijan antamia pisteitä verrattiin päätutkijan pisteytykseen. Tämän jälkeen joitakin indikaattoreita tai niiden sisältöjä täsmennettiin yhdenmukaisemman tulkinnan ja pisteytyksen varmistamiseksi. Täsmennettyjä indikaattoreita olivat muun muassa laajan terveystarkastuksen kriteerit sekä erityisen tuen tarpeen tunnistaminen ja tuen järjestäminen. Joitakin indikaattoreita siirrettiin myös ulottuvuudesta toiseen, esimerkiksi opettajan arvio oppilaasta siirrettiin yhteistyö-ulottuvuudesta laaja terveystarkastus - ulottuvuuden alle.

Mittarin päivittämisen jälkeen päätutkija luki toimintaohjelmat uudelleen aikaisempaa pisteytystä tarkistaen ja sitä tarvittaessa korjaten. Tämän jälkeen toinen tutkija teki reliabiliteettitarkistuksen samoin kuin ensimmäisellä kerralla. Muutoksia indikaattoreihin, niiden sisältöihin tai toimintaohjelmien pisteisiin ei enää tässä yhteydessä tehty, koska kahden tutkijan pisteytys oli riittävän yhtenevä.
Kahden tutkijan pisteytyksen yhdenpitävyyttä arvioitiin toimintaohjelmamittarin päivittämisen ja toimintaohjelmapisteiden tarkistamisen jälkeen. Vertailussa käytettiin painotettua Cohenin kappaa, joka laskettiin R-ohjelmiston paketilla irr (41). Cohenin kapan arvo asteikolla 0-1 oli 0.632 , jota yleisesti pidetään hyvänä yhdenpitävyytenä (42).

\section{TILASTOLLISET MENETELMÄT}

Tilastolliset analyysit tehtiin R-ohjelmiston versiolla 3.3.1 (43). Ulottuvuuksien väliset korrelaatiot mitattiin Spearmanin järjestyskorrelaatiokertoimella ja alueellisten erojen merkitsevyyttä testattiin yksisuuntaisella varianssianalyysillä.

\section{TULOKSET}

Toimintaohjelmapisteet vaihtelivat 0:sta 70 pisteeseen (0-92\% maksimista). Yhteensä 15 toimintaohjelmaa (11\%) saivat arviossa vähintään $75 \%$ mittarin maksimipisteistä eli 57 pistettä tai enemmän. Alle $25 \%$ maksimista sai 13 toimintaohjelmaa (10\%). Näistä kahdessa ei ollut kouluterveydenhuoltoa koskevaa tietoa lainkaan. Toimintaohjelmapisteiden keskiarvo oli 39.6 (Taulukko 3).

Kouluterveydenhuollon sisältö, joka koostui ulottuvuuksista laajat terveystarkastukset, muut terveystarkastukset ja terveysneuvonta sekä erityinen tuki, sai keskimäärin $55 \%$ maksimipisteistä ja suunnittelu ja johtaminen $47 \%$ (ulottuvuudet sitoutuminen, johtaminen, yhteistyö ja voimavarat). Ulottuvuuksista korkeimmat pisteet saivat muut terveystarkastukset ja terveysneuvonta (61\% maksimista) ja alhaisimmat pisteet voimavarat-ulottuvuus (34\%).

Indikaattoreista määräaikaisten terveystarkastusten (laajat terveystarkastukset, muut määräaikaiset ja suun terveystarkastukset) lukumäärät oli kirjattu asetuksen mukaisesti yli neljään toimintaohjelmaan viidestä (taulukko 2). Yhdeksän indikaattoria (24\%) sai alle neljäsosan indikaattorikohtaisesta maksimista. Näistä kuusi kuului suunnittelu ja johtaminen arviointikokonaisuuteen. Koululääkäreiden voimavarat oli kirjattu vain joka viidenteen toimintaohjelmaan $(21 \%)$. Alhaisimmat indikaattorikohtaiset pisteet sai lääkärivoimavarojen riittävyyden arviointi (12\% maksimista).

Toimintaohjelmien kokonaispisteet korreloivat positiivisesti terveyskeskuksen (väestöpoh- 
Taulukko 3. Toimintaohjelmapisteiden keskiarvo, kvartiiliväli sekä vaihteluväli ulottuvuuksittain.

\begin{tabular}{lccc}
\hline $\begin{array}{l}\text { Arviointikokonaisuus ja ulottuvuus } \\
\text { (ulottuvuuden maksimipistemäärä) }\end{array}$ & Keskiarvo & Kvartiiliväli & Vaihteluväli \\
\hline Kaikki yhteensä (76) & 39,6 & $30-51$ & $0-70$ \\
Johtaminen ja suunnitelmallisuus & & & \\
Sitoutuminen (10) & 5,3 & $3-7$ & $0-10$ \\
Johtaminen (12) & 5,7 & $3-8$ & $0-12$ \\
Yhteistyö (8) & 4,4 & $3-6$ & $0-8$ \\
Voimavarat (8) & 2,7 & $0-5$ & $0-8$ \\
Kouluterveydenhuollon sisältö & & & \\
Laajat terveystarkastukset (14) & 7,7 & $6-10$ & $0-14$ \\
Muut terveystarkastukset ja terveysneuvonta (12) & 7,3 & $6-10$ & $0-12$ \\
Erityinen tuki (12) & 6,5 & $4-10$ & $0-12$ \\
\hline
\end{tabular}

Taulukko 4. Terveyskeskusten toimintaohjelmapisteiden keskiarvo ulottuvuuksittain terveyskeskuksen väestöpohjan mukaan.

Terveyskeskuksen väestöpohja

$\begin{array}{llllll}\text { Ulottuvuus (ulottuvuuden } & \text { Alle 5000 5000-9999 } & 10000-19999 & 20000-49999 & \text { Yli } 50000\end{array}$ maksimipistemäärä)

\begin{tabular}{lccccc}
\hline Kaikki yhteensä (76) & 29,5 & 39,9 & 34,3 & 43,5 & 46,5 \\
$\begin{array}{l}\text { Suunnittelu ja johtaminen } \\
\text { Sitoutuminen (10) }\end{array}$ & 4,2 & 5,1 & 4,4 & 5,8 & 6,6 \\
Johtaminen (12) & 3,9 & 5,1 & 4,7 & 6,4 & 7,9 \\
Yhteistyö (8) & 3,1 & 5,2 & 3,3 & 4,9 & 4,8 \\
Voimavarat (8) & 0,8 & 3,3 & 2,4 & 3,0 & 3,6 \\
Kouluterveydenhuollon sisältö & & & & \\
Laajat terveystarkastukset (14) & 6,4 & 7,2 & 6,9 & 8,5 & 8,7 \\
$\begin{array}{l}\text { Muut terveystarkastukset ja } \\
\text { terveysneuvonta (12) }\end{array}$ & 5,8 & 7,6 & 7,3 & 7,6 & 7,3 \\
Erityinen tuki (12) & 5,3 & 6,3 & 5,4 & 7,3 & 7,8 \\
\hline
\end{tabular}

jan) koon kanssa (taulukko 4). Suurimpien (yli 50000 väestöpohjan) terveyskeskusten toimintaohjelmat saivat tilastollisesti merkitsevästi korkeammat kokonaispisteet pienempiin terveyskeskuksiin verrattuna $(r=0,29)$. Molemmat arviointikokonaisuudet toteutuivat suurimmissa terveyskeskuksissa myös pieniä paremmin (suunnittelu ja johtaminen $\mathrm{r}=0,29$, kouluterveydenhuollon sisältö $r=0,23)$. Tilastollisesti merkitsevä positiivinen yhteys löytyi lisäksi viiden ulottuvuuden ja väestöpohjan koon väliltä. Nämä olivat johtaminen $(r=0,34)$, laajat terveystarkastukset $(r=0,24)$, sitoutuminen $(r=0,24)$, erityinen tuki $(\mathrm{r}=0,20)$ ja voimavarat $(\mathrm{r}=0,20)$.

Toimintaohjelmien kokonaispisteet vaihtelivat huomattavasti eri terveyskeskusten ja maakuntien välillä (taulukko 5). Laajojen aluehallintoviratojen toimialueiden välillä toimintaohjelmapisteissä ei kuitenkaan todettu tilastollisesti merkitseviä eikä käytännön kannalta merkittäviä eroja. 
Taulukko 5. Terveyskeskusten toimintaohjelmapisteiden minimi, keskiarvo ja maksimi maakunnittain.

\begin{tabular}{|c|c|c|c|c|c|}
\hline \multirow[b]{2}{*}{ AVI } & \multirow{2}{*}{$\begin{array}{l}\text { Maakunta } \\
\text { (terveyskeskusten N) }\end{array}$} & \multicolumn{4}{|c|}{ Kokonaispistemäärä } \\
\hline & & Minimi & Keskiarvo & Maksimi $^{2}$ & $\mathrm{n}^{3}$ \\
\hline \multirow[t]{5}{*}{ Etelä-Suomi } & Uusimaa (19) & 21,0 & 40,3 & 67,0 & 14 \\
\hline & Kanta-Häme (4) & 33,0 & 46,8 & 60,0 & 4 \\
\hline & Päijät-Häme (4) & 32,0 & 48,3 & 58,0 & 4 \\
\hline & Kymenlaakso (5) & 26,0 & 40,4 & 70,0 & 5 \\
\hline & Etelä-Karjala (2) & 36,0 & 50,0 & 64,0 & 2 \\
\hline \multirow[t]{2}{*}{ Lounais-Suomi } & Varsinais-Suomi (15) & 19,0 & 35,4 & 49,0 & 11 \\
\hline & Satakunta $(8)$ &, 0 & 38,0 & 68,0 & 8 \\
\hline \multirow[t]{4}{*}{ 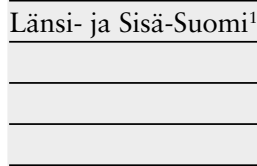 } & Pirkanmaa (16) & 11,0 & 37,9 & 57,0 & 15 \\
\hline & Keski-Suomi (6) & 34,0 & 41,3 & 50,0 & 6 \\
\hline & Etelä-Pohjanmaa (7) & 26,0 & 45,8 & 55,0 & 6 \\
\hline & Keski-Pohjanmaa (2) & 35,0 & 40,0 & 45,0 & 2 \\
\hline \multirow[t]{3}{*}{ Itä-Suomi } & Etelä-Savo (9) & 11,0 & 41,4 & 63,0 & 9 \\
\hline & Pohjois-Savo (7) & 20,0 & 34,8 & 62,0 & 6 \\
\hline & Pohjois-Karjala (10) & 17,0 & 36,6 & 65,0 & 8 \\
\hline \multirow[t]{2}{*}{ Pohjois-Suomi } & Pohjois-Pohjanmaa (20) & 10,0 & 37,5 & 60,0 & 20 \\
\hline & Kainuu (1) & 62,0 & 62,0 & 62,0 & 1 \\
\hline Lappi & Lappi (18) &, 0 & 38,9 & 61,0 & 15 \\
\hline
\end{tabular}

${ }^{1}$ Aineistossa ei ollut mukana yhtään toimintaohjelmaa Pohjanmaan maakunnan terveyskeskuksesta (4)

${ }^{2}$ Toimintaohjelmapisteiden teoreettinen maksimi 76 pistettä

${ }^{3}$ Aineistossa mukana olevien toimintaohjelmien määrä

\section{POHDINTA}

Kouluterveydenhuollon on kansallisten tavoitteiden mukaisesti oltava suunnitelmallista ja tasoltaan yhtenäistä koko maassa (1-6). Lakisääteinen toimintaohjelma toimii suunnittelun ja johtamisen apuna $(25,28)$. Tässä tutkimuksessa kehitetty toimintaohjelmamittari mahdollistaa kouluterveydenhuollon suunnittelun, johtamisen ja yhtenäisen tason vertailukelpoisen arvioinnin.

Ensimmäiset asetuksen mukaiset toimintaohjelmat olivat rakenteellisesti, sisällöllisesti ja laadullisesti vaihtelevia (28). Tässä tutkimuksessa vain joka kymmenes toimintaohjelma sisälsi arviomme mukaan säännöksiin $(5-6,24)$ nähden riittävät tiedot kouluterveydenhuollosta. Näitä olivat toimintaohjelmat, jotka saivat vähintään $75 \%$ toimintaohjelmamittarin kokonaispistemäärästä (57 pistettä tai enemmän). Suurimpien terveyskeskusten toimintaohjelmat saivat keskimäärin korkeammat pisteet. Näissä onkin eniten tarvetta yhtenäistää useiden toimintayksiköiden toimintaa. Myös suunnitteluun käytettävissä olevat voimavarat ovat todennäköisesti suurissa terveyskeskuksissa pieniä paremmat.
Toimintaohjelmiin on aikaisemman tiedon mukaan kirjattu monipuolisesti palveluihin ja niiden järjestämiseen liittyviä asioita, vaikka toimintaohjelmat olivat sisällöllisesti vaihtelevia (28). Arviomme mukaan määräaikaisten terveystarkastusten lukumäärät ja ajankohdat oli kirjattu toimintaohjelmiin pääosin hyvin. Sen sijaan terveystarkastusten yhdenmukaiset sisällöt oli usein kuvattu puutteellisesti. Laajan terveystarkastuksen valtakunnalliset kriteerit löytyivät joka kolmannesta (35\%) ja yhdenmukaiset sisällöt joka neljännestä toimintaohjelmasta. Muiden kuin laajojen määräaikaisten terveystarkastusten sisältöjä kuvattiin vain hieman paremmin (40 \%:ssa toimintaohjelmia). Määräaikaiset ja erityisesti laajat terveystarkastukset eivät tämän perusteella toteudu koko maassa tasoltaan riittävän yhtenäisinä ja laadukkaina.

Kouluterveydenhuollon henkilöstövoimavarat ovat kehittyneet suotuisasti vaikkakin riittämättömästi vuodesta 2008 lähtien (44). Henkilöstövoimavara- ja -mitoitustietoa löytyi toimintaohjelmista vain harvoin. Koululääkäreiden voimavaratietoa löytyi joka viidennestä toiminta- 
ohjelmasta ja arvio olemassa olevien lääkärivoimavarojen riittävyydestä joka kymmenennestä toimintaohjelmasta $(12 \%)$. Terveydenhoitajien voimavarat ja arvio voimavarojen riittävyydestä oli kirjattu hieman useammin $(48 \%, 30 \%)$. Henkilöstövoimavarojen suunnittelu ja arviointi suhteessa suosituksiin ei toimintaohjelmien perusteella näytä toteutuvan avoimesti ja läpinäkyvästi.

Kouluterveydenhuolto on tärkeä osa opiskeluhuoltoa (45). Yhteistyötä opiskeluhuollon kanssa olikin kuvattu lähes kolmessa neljästä toimintaohjelmasta. Sen sijaan toimintaohjelman valmistelu yhteistyössä terveystoimen sekä sivistys- ja sosiaalitoimen kanssa asetuksen edellyttämällä tavalla oli kirjattuna vain joka neljännessä toimintaohjelmassa. Toimintaohjelma-arvioinnin perusteella on pääteltävissä, että toimialojen yhteistyö kouluterveydenhuollon suunnittelussa ei toimi yhtä hyvin kuin monialaisen opiskeluhuollon yhteistyö. Lasten ja nuorten tarpeiden huomioimisen ja syrjäytymisen ehkäisyn systemaattisuuden varmistamiseksi myös erityisen tuen tarpeen havaitsemisen menetelmiä ja tuen järjestämisen käytäntöjä olisi hyvä kuvata toimintaohjelmissa nykyistä kattavammin.

\section{TUTKIMUKSEN HEIKKOUDET JA VAHVUUDET}

Toimintaohjelman avulla saadaan kokonaiskuva kouluterveydenhuollon järjestämisestä. Sen avulla voidaan arvioida toiminnan suunnittelua, johtamista, sisältöjä sekä yhtenäistä tasoa systemaattisesti ja vertailla terveyskeskuksia keskenään. Emme kuitenkaan voi pelkän toimintaohjelman perusteella olla varmoja siitä, että ohjelma kuvaa käytännön toimintaa ja myös ohjaa sitä. Tältä osin mittarin validiteettia olisikin hyvä tarkastella jatkotutkimuksin. Vaikka aineistomme kattoi $86 \%$ terveyskeskuksista, poisjääneiden mukaan saaminen olisi myös jossain määrin saattanut vaikuttaa tuloksiin. Kaikilla terveyskeskuksilla ei vielä niiden keräyshetkellä ollut asetuksen mukaista toimintaohjelmaa eikä näin kuvausta omasta toiminnastaan, mikä on myös voinut vaikuttaa tuloksiin.

Toimintaohjelmamittaria voidaan hyödyntää kouluterveydenhuollon seurannassa sekä paikallisesti itsearvioinnin, omavalvonnan ja toiminnan kehittämisen työkaluna. Mittaria on lisäksi mahdollista kehittää ja validoida muun vastaa- van toiminnan ja suunnitteluasiakirjojen arviointiin sopivaksi työvälineeksi. Eri tutkijoiden käyttämänä se näyttää antavan riittävän luotettavan kuvan tilanteesta.

\section{LOPUKSI}

Kouluterveydenhuollolla on merkittävä rooli lasten ja nuorten terveyden ja hyvinvoinnin edistämisessä (1). Tasoltaan yhtenäinen ja laadukas toiminta edellyttää hyvää suunnittelua ja johtamista sekä toiminnan kehittämistä lasten, nuorten ja perheiden tarpeiden mukaisesti. Kouluterveydenhuollon ensimmäisten toimintaohjelmien rakenne, sisältö ja laajuus vaihtelivat huomattavasti. Korkeimmat pisteet saaneet toimintaohjelmat olivat konkreettisia, henkilöstöä ohjaavia ja toimintaa yhdenmukaistavia suunnitteluasiakirjoja. Ne oli myös valmisteltu ja suunniteltu yhteistyössä sivistys- ja sosiaalitoimen kanssa asetuksen mukaisesti.

Tutkimuksemme antaa vertailutietoa kouluterveydenhuollon suunnittelusta, sisällöistä ja toiminnan tason yhtenäisyydestä. Toimintaohjelmaarvioinnin avulla voidaan tunnistaa ne terveyskeskukset, joissa kouluterveydenhuolto todennäköisimmin toteutuu kansallisten tavoitteiden mukaisesti. Arvioinnin tulokset voidaan myös jatkossa yhdistää muuhun kouluterveydenhuollosta saatavaan tietoon, jolloin näkemys käytännön toiminnan toteutumisesta tarkentuu. Tämän jälkeen voidaan edelleen arvioida kouluterveydenhuollon laajojen terveystarkastusten vaikutuksia muiden sosiaali- ja terveyspalveluiden käyttöön.

Suosittelemme toimintaohjelmamittaria käytettäväksi kouluterveydenhuollon seurannassa. Toimintaohjelma-arvioinnin tuloksia voidaan lisäksi hyödyntää kouluterveydenhuollon ohjauksessa ja valvonnassa sekä palveluja kehitettäessä sosiaali- ja terveydenhuollon uudistuksen yhteydessä kouluterveydenhuollon järjestämisvastuun siirtyessä kunnilta maakunnan vastuulle.

\section{KIITOKSET}

Esitämme kiitokset aluehallintovirastojen terveydenhuollon henkilöstölle, joka toteutti toimintaohjelmien keräämisen alueensa terveyskeskuksista sekä sosiaali- ja terveysalan lupa ja valvontavirasto Valviralle mahdollisuudesta käyttää toimintaohjelmia tässä tutkimuksessa. 


\section{KIRJOITTAJIEN KONTRIBUUTIOT}

Frantsi-Lankia osallistui tutkimuksen suunnitteluun, aineiston keräämiseen ja arviointiin, arviointimallin kehittämiseen ja käsikirjoituksen laatimiseen. Kivimäki ja Wiss osallistui tutkimuksen suunnitteluun, arviointimallin kehittämiseen ja kommentointiin. Saaristo teki tilastolliset ajot, osallistui tutkimuksen suunnitteluun, arviointimallin kehittämiseen ja kommentointiin. Ståhl ohjasi tutkimusta, osallistui tutkimuksen suunnitteluun, arviointimallin kehittämiseen ja kommentointiin. Rimpelä oli päävastuussa ohjauksesta ja osallistui tutkimuksen suunnitteluun, arviointimallin kehittämiseen ja kommentointiin. Kaikki kirjoittajat hyväksyivät lopullisen käsikirjoituksen.

Frantsi-Lankia, M., Kivimäki, H.,Wiss, K., Saaristo, V., Ståhl,T., Rimpelä,A. Measuring management, regional equity and performance of school health services with the help of local government action plans Sosiaalilääketieteellinen aikakauslehti- Journal of Social Medicine 20 I 8: 55: I 06-I 16

The guiding principle of school health services, organized by local governments, is equal access to high quality preventive services for every schoolchild. According to the Act on Maternity and Child Health Clinic Services, School and Student Health Care, Preventive Oral Health Care for Children and Young people (2009), local governments are required to make an action plan of organizing and carrying out these services. The aim of this study was to formulate a measurement tool for evaluating management, regional equity and performance of school health services. Action plans are used as empirical material. In 2011-2012, Regional State Administrative Agencies $(n=6)$ collected action plans from the local governments $(\mathrm{N}=136$, response rate $87 \%$ ). The measurement tool, created for this purpose, had two parts (planning and management, content of school health service) and seven dimensions (commitment, management, collaboration, resources, comprehensive health examination (new), traditional school health procedures , and special support), which were measured using 38 indicators. Only the parts of the action plans dealing with school health services were used. The maximum total score of all indicators was 76. The total score of action plans varied from 0 to 70 . The mean score was $39.6(52 \%$ of the maximum score). Only fifteen action plans $(11 \%)$ got at least $75 \%$ of the maximum score. Resources had the lowest score $(2,7 / 8)$ of the seven dimensions and the traditional school health procedures had the highest score (7,3/12). Action plans of local governments with large populations score higher (46.50) than ones with smaller populations (29.50). Regional differences were observed. This study shows the action plans of local governments for school health services vary greatly and suggests a shortage in planning and management of school health services. Our conclusion is that the new measurement tool we developed is a useful instrument for evaluating school health services in a comparable way over the country. The results of the present study can be used as a baseline when assessing the effects of the forthcoming health care reform where the organisation of services, including school health services are transferred from local governments to regional ones.

Keywords School health services, action plan, measuring, measurement tool

Saapunut 8.4.2017

Hyväksytty 28.9.2017 


\section{LÄHTEET}

1. Stakes. Kouluterveydenhuolto 2002. Opas kouluterveydenhuollolle, peruskouluille ja kunnille. Oppaita 51. Helsinki 2002.

2. Sosiaali- ja terveysministeriö ja Suomen Kuntaliitto. Kouluterveydenhuollon laatusuositus. Oppaita 2004:8. Helsinki 2004.

3. Sosiaali- ja terveysministeriö. Asetus neuvolatoiminnasta, koulu- ja opiskeluterveydenhuollosta sekä lasten ja nuorten ehkäisevästä suun terveydenhuollosta. Työryhmän muistio. Selvityksiä 2008:37. Helsinki 2008.

4. Sosiaali- ja terveysministeriö. Neuvolatoiminta, koulu- ja opiskeluterveydenhuolto sekä ehkäisevä suun terveydenhuolto. Asetuksen (380/2009) perustelut ja soveltamisohjeet. STM 2009:20. Helsinki 2010.

5. Valtioneuvoston asetus neuvolatoiminnasta, koulu- ja opiskeluterveydenhuollosta sekä lasten ja nuorten ehkäisevästä suun terveydenhuollosta 28.5.2009/380. http://www.finlex.fi/fi/laki/alkup/2009/20090380

6. Valtioneuvoston asetus neuvolatoiminnasta, koulu- ja opiskeluterveydenhuollosta sekä lasten ja nuorten ehkäisevästä suun terveydenhuollosta 6.4.2011/338. http://www.finlex.fi/fi/laki/alkup/2011/20110338

7. Perälä M-L, Halme N, Nykänen S, ym. Lasten, nuorten ja perheiden palveluja yhteensovittava johtaminen. Opas 19. Tampere: Terveyden ja hyvinvoinnin laitos; 2012.

8. Rimpelä A, Caan W, Bremberg S, ym. Schools and the health of children and young people. Kirjassa: Wolfe I ja McKee M (toim) European Child Health Services and Systems. Lessons without borders. Maidenhead Bershire: Open University Press; 2013,145-82.

9. Kansanterveyslaki 25.5.2007/626. http://www.finlex.fi/fi/laki/ajantasa/1972/ 19720066

10. Lääkintöhallitus. Ohjeita kansanterveyslain edellyttämästä kouluterveydenhuollosta. DNo 9927/522/72. Helsinki 1972.

11. Lääkintöhallitus. Lääkintöhallituksen ohjekirje. Ohjeet kouluterveydenhuollosta. Helsinki 1981.

12. Rimpelä M, Wiss K, Saaristo V, ym. Kouluterveydenhuollon laatusuosituksen toimeenpano 2004-2007. Työpapereita 32/2007. Helsinki: Stakes; 2007.

13. Rimpelä M, Ojajärvi A, Luopa P, ym. Kouluterveyskysely, kouluterveydenhuolto ja terveystieto. Perusraportti kyselystä yläkouluille ja terveyskeskuksille. Työpapereita 1/2005. Helsinki: Stakes; 2005.

14. Latikka AM, Perälä ML, Hemminki E, ym. Kouluterveydenhuollon muutokset 1992-1994. Suom Lääkäril 1995;50:349-53.

15. Paakkonen T. Lasten ja nuorten mielenterveyspalvelujärjestelmä vaikeahoitoisuuden näkökulmasta. Kuopio: Itä-Suomen yliopisto; 2012.
16. Bardy M, Salmi M, Heino T. Mikä lapsiamme uhkaa? Suuntaviivoja 2000-luvun lapsipoliittiseen keskusteluun. Raportteja 263. Helsinki: Stakes; 2001.

17. Wiss K, Kivimäki H, Kosunen E, ym. Kouluterveydenhuollon henkilöstössä suuria eroja. Suom Lääkäril 2007;62:53-9.

18. Kivimäki H, Saaristo V, Kosunen E, ym. Kouluterveydenhuollon käynnit 1994-2005 - Toteutuiko tasa-arvo terveyskeskusten välillä informaatio-ohjauksen aikakaudella? Sosiaalilääk Aikak 2007;44:207-215.

19. Valtiontalouden tarkastusvirasto. Kouluterveydenhuollon laatusuositus - suosituksen ohjausvaikutukset kuntien toimintaan. Tarkastuskertomus 136/2006. Helsinki 2006.

20. Apulaisoikeuskansleri Jonkka J. Kouluterveydenhuollossa ongelmia. Tiedote 16.2.2007. Oikeuskanslerin virasto 2007. Luettu 9.2.2017. http://www.okv.fi/suomi/tiedote/t070216f.htm

21. Kivimäki H, Kosunen E, Rimpelä A, ym. Suunnitelmallisuus puuttuu peruskoulujen kouluterveydenhuollosta. Suom Lääkäril 2007;62:61-7.

22. Lastensuojelulaki 13.4.2007/417. http://www.finlex.fi/fi/laki/ajantasa/2007/ 20070417

23. Määttä M, Väänänen-Fomin M. Yhteinen tavoite, eriytyneet ohjausjärjestelmät - lasten ja nuorten hyvinvointiin liittyvän suunnittelun normiohjaus. Kirjassa: Raitakari S, Virokannas E (toim.) Nuorisotyön ja sosiaalityön jaetut kentät. Helsinki: Nuorisotutkimusverkosto; 2009,63-80.

24. Terveydenhuoltolaki 30.12.2010/1326. http://www.finlex.fi/fi/laki/ajantasa/2010/ 20101326

25. Hakulinen-Viitanen T, Hietanen-Peltola M, Hastrup A, ym. Laaja terveystarkastus. Ohjeistus äitiys- ja lastenneuvolatoimintaan sekä kouluterveydenhuoltoon. Opas 22. Helsinki: Terveyden ja hyvinvoinnin laitos; 2012.

26. Ståhl T, Saaristo V. Neuvolatoiminta, koulu- ja opiskeluterveydenhuolto sekä lasten ja nuorten ehkäisevä suun terveydenhuolto 2009. Raportti 21/2011. Helsinki: Terveyden ja hyvinvoinnin laitos; 2011.

27. Wiss K, Frantsi-Lankia M, Koskinen H, ym. Neuvolatoiminta, koulu- ja opiskelijaterveydenhuolto sekä lasten ja nuorten ehkäisevä suun terveydenhuolto 2011. Asetuksen (338/2011) toimeenpanon seuranta ja valvonta. Raportti 71/2012. Helsinki: Terveyden ja hyvinvoinnin laitos; 2012.

28. Hakulinen-Viitanen T, Hietanen-Peltola M, Bloigu A, ym. Äitiys- ja lastenneuvolatoiminta ja kouluterveydenhuolto. Valtakunnallinen seuranta 2012. Raportti 12/2014. Helsinki: Terveyden ja hyvinvoinninlaitos; 2014.

29. Groene O, Garcia-Barbero M. Health promotion in hospitals: Evidence and quality management. WHO; 2005. Luettu 9.2.2017. http://www.euro.who.int/_data/assets/pdf_ file/0008/99827/E86220.pdf 
30. Unesco. Monitoring and evaluation guidance for school health programs. Eight core indicators to support FRESH. 2013. Luettu 9.2.2017. http://www.schoolsandhealth.org/Pages/ LinksDocuments.aspx

31. European Foundation for Quality Management. An Overview of the EFQM Exellence Model. Bryssel 2013. Luettu 9.2.2017. http://www.efqm. org/sites/default/files/overview_efqm_2013_vl.pdf.

32. WHO. European framework for quality standards in school health services and competences for school health professionals. Copenhagen: WHO; 2014.

33. Centers for Disease Control and Prevention. School Health Index: A Self-Assessment and Planning Guide. Elementary school version. Atlanta, Georgia. 2012. Luettu 9.2.2017. http://www.cdc.gov/HealthyYouth/SHI/

34. Aluttis C, Van den Broucke S, Chiotan C, ym. Public health and health promotion capacity at national and regional level: a review of conceptual frameworks. J Public Health Res 2014;3(199): 37-42. https://doi.org/10.4081/jphr.2014.199

35. WHO. Rapid assessment and action planning process (RAAPP). A Method and Tools to Enable Ministries of Education and Health to Assess and Strengthen their Core Elements of Capacity to Promote Health Through Schools. A Presentation by Education Development Center. WHO. Luettu 9.2.2017.

http://www.who.int/school_youth_health/ assessment/raapp/en/

36. Lewallen TS, Hunt H, Potts-Datema W, ym. The Whole School, Whole Community, Whole Child Model: A New approach for Improving Educational Attainment and Healthy Development for Students. J Sch Health 2015;85(11):729-39. https://doi.org/10.1111/josh.12310

37. Ståhl T, Rigoff A-M, Saaristo V, ym. Terveyden edistämisen vertailutieto (TedBM) -hankkeen loppuraportti. Avauksia 9/2010. Helsinki: Terveyden ja hyvinvoinninlaitos; 2010.

38. Saaristo V, Alho L, Ståhl T, ym.

Terveydenedistämisaktiivisuutta perusterveydenhuollossa kuvaavat tunnusluvut ja niiden raportointi - menetelmäraportti. Avauksia 10/2010. Helsinki: Terveyden ja hyvinvoinninlaitos; 2010.

39. Saaristo V, Ståhl T. TEAviisari 2010 - perusterveydenhuollon menetelmäraportti. Raportti 35/2011. Helsinki: Terveyden ja hyvinvoinninlaitos; 2011.

40. Valvira. Neuvolatoiminta, koulu- ja opiskeluterveydenhuolto sekä lasten ja nuorten ehkäisevä suun terveydenhuolto. Valtakunnallinen valvontaohjelma 2012-2014. Valvontaohjelmia 1:2012. Helsinki 2012. Luettu 27.10.2016. http://www.valvira.fi/files/tiedostot/n/e/ Neuvolatoiminta_valvontaohjelma.pdf
41. Gamer M, Lemon J, Fellows I, ym. Irr: Various Coefficients of Interrates Reliability and Agreement. R Package version 0.84. 2015. https:// CRAN.R-project.org/package=irr.

42. Landis JR, Koch GG. The measurement of observer agreement for categorical data. Biometrics 1977;33(1):159-74. https://doi.org/10.2307/2529310

43. R Core Team. R: A language and environment for statistical computing. R Foundation for Statistical Computing. Wien 2014. http://www.R-project.org/.

44. Wiss K, Ståhl T, Saaristo V, ym. Terveydenhoitajat, lääkärit, psykologit ja kuraattorit peruskouluissa 2008-2015. Suom Lääkäril 2017;3:127-31.

45. Oppilas- ja opiskelijahuoltolaki 30.12.2013/1287. http://www.finlex.fi/fi/laki/alkup/2013/20131287

\section{MARJUT FrantSI-LANKIA \\ LL, asiantuntijalääkäri \\ Kela}

\section{HANNE KIVIMÄKI \\ TtM, tutkija \\ Terveyden ja hyvinvoinnin laitos \\ Lasten, nuorten ja perheiden yksikkö, Hyvinvointiosasto}

\section{KIRSI WISS}

$T t M$, asiantuntija

Terveyden ja hyvinvoinnin laitos

Hyvinvoinnin ja terveyden edistämisen yksikkö, Hyvinvointiosasto

\section{VeSA SAARISTO \\ FM, asiantuntija \\ Terveyden ja hyvinvoinnin laitos \\ Hyvinvoinnin ja terveyden edistämisen yksikkö, Hyvinvointiosasto}

TIMO STÅHL

$T t T$, dosentti, johtava asiantuntija

Terveyden ja hyvinvoinnin laitos

Hyvinvoinnin ja terveyden edistämisen yksikkö, Hyvinvointiosasto

\author{
ARJA Rimpelä \\ LT, kansanterveystieteen professori \\ Yhteiskuntatieteellinen tiedekunta/Terveystieteet \\ Tampereen yliopisto \\ Nuorisopsykiatria \\ Tays Pitkäniemen sairaala
}

